\title{
WHAT IS VERNACULAR CATHOLICISM? THE "DIGNITY” EXAMPLE
}

\author{
Leonard Norman PRIMIANO \\ Cabrini College \\ 610 King of Prussia Road, Radnor, PA 19087-3698 USA
}

\begin{abstract}
The fact of Christianity's negative attitude toward homosexual relations has not stopped a large number of gay and lesbian Christian believers from continuing to think of themselves as members of their respective denominations. In many American metropolitan settings, groups of homosexual Roman Catholics have formed a religious organisation named 'Dignity' to fulfill a need for worship and socializing.

Focusing on the Philadelphia branch of Dignity, this paper examines the reasons for the continued involvement by homosexual American Catholics in religion in general and in such an antagonistic religious institution in particular. The study of the sexual politics of this Dignity congregation has generated a new perspective which underscores the insufficiency of the conventional terminology of "sectarian," "popular," or even "official," religion for describing the vitality of lived religion. In response, I offer the term "vernacular religion" which will be explained and assessed as a new approach in the search for understanding of any given community of believers and their various categories of religious belief. The relation of the study of vernacular religion to the Philadelphia Dignity community will be discussed through an examination of its history and developments; of the negotiated beliefs of its members; and its reactions to the institutional church, and to the AIDS crisis.

Keywords: Christianity, homosexuals, homosexual organizations, 'Dignity community,' vernacular religion
\end{abstract}

At the 1999 SIEF Symposium and in this published text considering the topic, "Folk Religion and Politics," it was my desire to broaden the scope of consideration beyond the relationship of vernacular religion to the science of governmental/national politics. I wished to include as a part of our discourse the politics of religious institutions, the politics of creating theology, and the politics of sexual morality within a religious tradition like Roman Catholicism. ${ }^{1}$

Although the documents of the Second Vatican Council emphasize the need to understand Catholicism in much broader terms, many contemporary leaders of the Church themselves tend to reify the institution's authoritarian nature as the dichot-

${ }^{1}$ William WESTERMAN has delineated in a useful encyclopedia article "seven distinct but interrelated areas of folklore and folklife research" associated with the study of politics and folklore (WESTERMAN 1996: 570-574). Particularly relevant to the study of vernacular religion and its multitude of expressions is his sixth category: folk political organization and alternative social institutions. WESTERMAN argues that the ideologies of religious settlements and cooperative communities "are commentaries on existing in the face of a larger dominant culture and are creative ways to dispense with aspects of the dominant culture that are unacceptable to adherents" (1996: 574). 
omy between a clerical elite maintaining rules and a practicing laity absorbing them. Of course, the hierarchy even in the process of the performance of their sacerdotal functions are also creatively negotiating their understanding of Catholicism, making it the normative understanding because of the roles they occupy as "specialists" in the religious institution. This kind of creative negotiating, it should be noted, takes place throughout the Church.

One example of negotiation within the Church that I have researched is Dignity (Primiano 1993a; 1993b), the Philadelphia, Pennsylvania, chapter of the "national lay movement of lesbian, gay, bisexual and transgendered [Roman] Catholics, their families and their friends" (HELMINIAK 1996). The men and women who have banded together to form this community share with all other Catholics the intrinsic action of negotiating their religious lives. I have identified this activity of people creating their own religion as "vernacular religion." Vernacular religion, as I have categorized it, is religion as it is encountered, understood, interpreted, and practiced (PRIMIANO 1995: 44), and the members of Dignity that I have studied particularly exemplify its basic principles. For in their process of learning and sustaining their religion, these Catholics have negotiated their institutions, their beliefs, their public ritual activities, their private devotions and practices, their interactions with other believers, and their material lives including clothing, food, domestic space, religious objects, and the life of the body.

While there are many gay and lesbian Roman Catholics who continue as faithful members in traditional parish settings, some have banded together for this national organization which is composed of a number of independent regions and communities throughout the United States and Canada. Dignity/Philadelphia described itself in their 1987 Information Sheet with the following statement:

DIGNITY/PHILADELPHIA is a chartered Chapter of DIGNITY, INC., an international movement of gay and lesbian Catholics and their friends, working within the Church for the development of its sexual theology, for the acceptance of gay and lesbian persons as full and equal members, and to elicit responsive approaches both inside and outside the entire Roman Catholic Church. (Dignity/Philadelphia Information Sheet: 1987)

Dignity has played a unique role in the history of post-Vatican II American Catholicism as one of the most successful gay/lesbian affinity groups of any Christian denomination in the United States. ${ }^{2}$ The organization provides spiritual, educa-

\footnotetext{
2 Dignity literature gives membership rates of 125 in 1977 and 122 in 1982.167 members was the number stated at the Philadelphia group's Quarterly Business Meeting (16 February 1986) and 152 members was stated at the Quarterly Business Meetings (10 August and 9 November 1986). In 1989, the Philadelphia membership numbered 225 men and women, with the proportion of women in the chapter remaining ten percent or less. The Chapter reached its highest membership in 1990-1991 with 250 members. Most recent memberships rates have been lower: 190 individuals paid dues with about $11 \%$ of those belonging to women (1996).
} 
tional, and social goals, as well as counseling services for its members. The first Dignity chapter was established in San Diego, California, in 1969. Dignity/Philadelphia traces its origins back to a series of home liturgies that began in 1973. Its existence has never been sanctioned by the Archdiocese of Philadelphia, and Dignity's liturgical or business activities have never been permitted to take place on Church property. For most of its existence, the chapter has rented space in Episcopal Church halls and sanctuaries.

While keeping the issue of Catholic hierarchical treatment of and concern for homosexual persons before the institutional Church and the general public, Dignity has never broken from the institutional Church. It has retained an allegiance to Roman Catholic dogma and tradition while, at the same time, maintaining the central principle that it is not immoral for a gay or lesbian Catholic to live an actively homosexual life. Though not recognized by the institutional Church, Dignity as a lay-run Catholic community has achieved sufficient notoriety to prompt responses to their activities from both the Vatican and American Church hierarchy. ${ }^{3}$

Given their situation as homosexual Catholics battling with most members of the hierarchy of their Church and certainly with Vatican authorities, these Catholics have been challenged to interpret their religion to make it relevant to their lives. They consciously added to or subtracted from the Catholic faith as they understood it, and to their satisfaction. One Dignity member described this action, what he called "rationalizing" the diverse elements of his "lived experience," as the "the gymnastics of faith." Others described this practice in the same manner as did nongay Catholics of the post-Vatican II period as being "à la carte," "cafeteria," "peripatetic," and "pick-and-choose" Catholics. Father Jake, the undesignated chaplain of Philadelphia/Dignity, highlighted this vernacular process of negotiation when he employed a dining theme to explain to me how he made decisions about his religious life:

LNP: Now, what would you say if someone said to you that you're involved in a theological cafeteria?

CHAP: That may be true, [but] what is theology? Maybe that's where it needs to be done [in] some cafeteria. Because we are talking about food and drink, whether it be intellectual or spiritual or pastoral. We're talking about feeding: take and eat, feed my sheep ... the food of life, the source of life. OK, I am [choosing] food in a cafeteria.

LNP: At the same time, you're deciding that sometimes what the chef serves, you don't have to take.

CHAP: And I don't have to.

\footnotetext{
${ }^{3}$ The most prominent statement reaffirming the Church's critical moral stance on homosexual genital activity was the "Letter to the Bishops of the Catholic Church on the Pastoral Care of Homosexual Persons." This letter was promulgated in 1986 by the Vatican's Congregation for the Doctrine of the Faith (See GRAMICK and FUREY 1988). See HELMINIAK (1998) and STONE (1998) for a discussion of other late twentieth-century statements by the Vatican and American bishops on homosexuality as well as the role of Dignity in contemporary Catholic discourse on same-sex relationships.
} 
LNP: Because you're very perfectly nourished by the foods that you're able to choose from the line yourself?

CHAP: Yes, because they have all been produced by the chef. I don't have to eat everything that the chef puts out. Nor do I have to be goggle-eyed over his special dish, I might get sick. Yes, since the chef brought this out, if I was present when he produced this fantastic thing and I said could I...really have the recipe for that? And he said: oh sure, here. And then next week he decides that never ever will this food be served again, and I'm over here with the recipe saying: Tough, I liked it. And I have a good reason [for this thinking] and that is theology. We must make a distinction between theology and authority, and maintain the authority of theology.

The vernacular religious life is influenced by any number of available resources, and for Catholics the multitude of beliefs and practices represented within institutionalized and non-institutionalized Catholicism form a rich source of inspiration within the process of believing. Dignity Catholics such as its de facto chaplain were aided in their re-creation of their religion by the institutional Church itself which underscored for the faithful the importance of the primacy of conscience in the documents of the Second Vatican Council. Dignity members, like many other American Catholics who disagreed, for example, with the Church's stances on sexual morality (from artificial contraception to divorce to abortion) traced the importance of conscience down through the centuries affirming the chaplain's perspective that "the ultimate right of the individual's conscience has really been maintained by the Church throughout the ages." The authority of theology that he referred to in our conversation was the primacy of his own reflections and conscience in achieving a satisfying religious life. He felt a sense of creative control over his own religious destiny, and he had no intention of relinquishing that personal responsibility. His keen understanding and interpretation of how Catholic theology worked allowed him to use the hierarchy's own instruments of doctrinal order and control to empower his religious life. This man's theological sensitivity is an outstanding example of his personal transformation of an "official" concept of Church into an experiential model suited to his spiritual, psychological, and social needs.

Dignity members like other Roman Catholics found the inspiration for their religious lives in the sacred sources, traditions, and history of the Church, as well as their personal reflections on their lived experiences. They saw their identities as religious men and women, and homosexual men and women, fulfilled in their own understanding of the Catholic faith and Catholic community. This is why they could remain within a religious tradition when the public representatives of that tradition treated them so negatively. For the same reason, both extreme traditionalists and extreme liberals, all actively gay, all Roman Catholic, all vernacularly Catholic, could be found worshipping together at Dignity.

The term, "vernacular Catholicism," is the final synthesis of my understanding of the vernacular religious process and its particular expression within the Catholi- 
cism of actual believers. Vernacular Catholicism is the uniquely Catholic formulation of the vernacular religious impulse shared by all religious people. It is the way a Catholic individually expresses his or her understanding of the Catholic tradition which is the history, structures, laws, customs, beliefs, and practices of its people. Vernacular Catholicism involves absorbing, learning, accepting, changing, denying, embellishing, and appreciating the spiritual and cultural parameters of Catholicism in one's life. It is manifested by Catholic believers and evidenced within the widest range of Catholic institutions: ${ }^{4}$ the Vatican hierarchy; the vast system of clerical functionaries throughout the universal Church; sacred environments and objects; scripture and interpretation; dogmatic pronouncements and doctrinal explanations; liturgy and paraliturgical practices including the Mass, the sacraments, pilgrimage, and devotions; the monastic communal and religious life; educational organizations including seminaries, the parochial school system, and the missions; the parish system; Christian base communities; lay social and spiritual organizations; religious festivals and public celebrations; private belief, devotionalism and religious practices; and the individual uses of sacramentalism.

Expressions of vernacular Catholicism can be observed within Dignity as within the Catholic community at large through two specific contexts: the religious beliefs and practices of the individual Catholic and the vernacular religion of the group. Although there is much that can be analyzed about the vernacular religion of the group, I mainly concentrate in this article on the vernacular religion of the individual because it is there that vernacular religious creativity can be seen most vividly.

At the individual level, Dignity members manifested the same kind of traditional piety, creative devotionalism, individual behaviors and opinions as could be seen at any other Catholic home, parish, or gathering. Such expressions could be observed in specific ways: gestures (for example, at a Dignity Mass in New York City, I recall seeing a man holding the hand of the statue of the dead Jesus as he placed the Communion wafer in his mouth); narratives (for example, an informant related to me a complex memorate and spiritual insight about Jesus' Sacred Heart and the Real Presence); attention to religious material culture (for example, mass-produced religious ephemera, such as holy cards and inexpensive prayer books, were often found at the Dignity information table before and after Sunday liturgy); paraliturgical gatherings (for example, a Dignity prayer group met weekly for the recitation of the rosary); cultural habits (for example, like many American Catholics some members of Dignity rushed to exit the Mass immediately after the distribution of Communion); personal opinions (for example, feelings of anticlericalism such as those directed at the local archbishop); or personal decisions about religion (for example, decisions to attend Mass at local archdiocesan parishes on occasion as well as the evening Dignity service).

\footnotetext{
${ }^{4}$ By institutions, I mean not only social entities, but also the individual formulation, creation, and sustaining of ongoing structure within people's lives exemplified by the term "uniculture" (See PRIMIANO 1995: 49-50).
} 
Of course, such expressions of traditional piety, personal experience narrative, personal decisions, etc. had the additional quality for Dignity members of being filtered and negotiated through their unique perspective within the Church. The weekly prayer service and recitation of the rosary by more conservatively minded members was specifically intended as a prayer for those suffering from AIDS within the gay community. The anticlerical feelings regarding the Church's hierarchy were directed against their refusal to acknowledge or support their gay flock. This is not to say that Dignity members could never relate to their religion without a gay reference, but they did possess a strong sense of themselves as gay people. Their time at Dignity insured an exposure to gay concerns and a gay male culture that comforted some, bothered others, but seemed to instill in most a sense of community (see PRIMIANO 1993b).

When these Catholics meditated on Christ, they were thinking of him as a single man among other men, and for some as the man who had a special friendship with his apostle, John. When they thought of the Virgin Mary, they personalized that devotion thinking of her as their own mother, the mother of a son who never married, and who did not fulfill the heterosexual expectations of his day. My informant, who told me of his supernatural insight about the mysteries of the Sacred Heart of Jesus, experienced in his daily reception of the Eucharist at a local parish an intense understanding of his relationship with Jesus, one which richly detailed a personal meshing of both Catholic and gay sensibilities. He noted:

Communion kept me together, and every day I felt like this unconditional love had loved me and then I'd go off to my dark night of confusion and misery [as a gay man]. But I always felt that for this early morning hour this love had come and really loved me, and that was really great, and I felt the Sacred Heart of Jesus was for me all the intensity of love I could have ever wanted to experience from a human person. It was like this man came to me everyday and he loved me everyday, and Jesus was his name.

The process of negotiation emerging from the interpretations of religion in the individual Catholic's life has been in evidence throughout the history of the Roman Catholic tradition influencing everything from personal practice to the codification of belief within institutions. From the rise of the cult of the saints to post-industrial Marian pilgrimage and from the formation of Dignity Masses to the writings of Cardinal Joseph Ratzinger about homosexual people from the Congregation For The Doctrine of the Faith - all these expressions involve believers in personal acts of interpretation of religious belief and practice. The vernacular process begins with the synthesis of an original vernacular religious insight with the social interaction of family, community, and tradition. The original vernacular creations of individuals most certainly will be lost over time, but a rich process of vernacular interpretation continues whether it involves a believer in acts of preservation, innovation, or radical change. Through the agreement of a community of like-minded individuals, inter- 
pretations can be preserved and concertized as religious institutions. While the vernacular religious voices of the original individuals may be obscured, the creative action of the constant negotiation of religion remains a consistent quality within those institutions.

At the community level, Dignity, in 1985, embarked on an ambitious plan to present its own statement on sexual ethics "to our brothers and sisters in the lesbian and gay community, and to the wider Church" (1989:2). It was the desire of its leaders in both Philadelphia and throughout the country that this document would complement Dignity's mission as a support group and community of resistance. These functions needed to continue because the constant flow of people passing through the chapter, and the long time members, needed varying levels of support due to their different stages of acceptance of their homosexuality. Dignity's core members, however, wanted to do more than simply be a movement on the defensive. What individuals desired was for Dignity to behave like the institutional Church and theologize, but using the membership's own perspectives on sexuality shaped from their own individual lives as the foundation. As I was told by a chapter President: "Because up until now Dignity has been trying to, as it were, defend its existence, once we get beyond that point of no longer having to fight for survival, then we can begin to discuss principles like genital activity, and promiscuity, etc."

This idea of incorporating the voices of the faithful into theological statements concerning them was felt to be the style of theologizing in the spirit and letter of the documents of the Second Vatican Council. The preparation of a statement on sexual ethics represented a challenge to the authority of the Catholic hierarchy to be the sole providers of theological direction and policy about sexual ethics in general, and about the sexual morality of gays and lesbians in particular. Jake, who was a member of the Sexual Ethics Task Force, noted: "We are beginning to move into that area of a self-reflection or a self-examination in light of Gospel values as they apply to our lifestyle rather than to justify our lifestyle in light of Gospel principles for somebody else." Dignity as an organized group wished to represent the lived experiences and personal negotiations of its members in its own statement of sexual theology. This action formally completed in 1989 and published as "Sexual Ethics: Experience, Growth, Challenge," was a formal attempt at theologizing by a community of North American Catholics about themselves and a challenge to the traditional structure of Roman Catholic authority on statements of morals.

Dignity Catholics are in many ways interpreting institutionalized religious beliefs, attitudes, images, and rituals to suit the way they want to express their personal relation to the sacred. Their expressions of personal faith reflect the dual nature of their experience of religion which both disempowers and empowers them. Their empowering expressions of faith reflect a creativity, an artistry, if you will, of religious expression and self-interpretation integral to the negotiations of vernacular religion.

Dignity members have brought what they have felt and learned as gay people to their experience as Roman Catholics. The amazing fact of Dignity Philadelphia's faith is vernacular Catholicism. Their ability to sustain and even nurture religious 
belief and association with the Church in the face of rejection and exclusion points to religious motivations related to their intrinsically Catholic lives. Their integration of gay and Catholic identities, validated both by individual and communal experience, is exemplary of the influence of vernacular Catholicism and the omnipresence of vernacular religion which represents the practiced religion of all believers.

\section{ACKNOWLEDGEMENT}

I wish to thank all of the members of Dignity/Philadelphia who spoke with me. Many thanks to Deborah Ann Bailey, Justin Falciani, Lars Jenner, Anne Jenner, and Kathleen Malone O'Connor for their editorial assistance and support.

\section{LITERATURE}

Dignity/Philadelphia Information Sheet 1987

Dignity/USA

1989: Sexual Ethics: Experience, Growth, Challenge. In Dignity/USA XXI (December): 2-16.

GRAMICK, Jeannine and FUREY, Pat (eds.)

1988: The Vatican and Homosexuality: Reactions to the "Letter to the Bishops of the Catholic Church on the Pastoral Care of Homosexual Persons." New York: Crossroad.

HELMINIAK, Daniel A.

1996: Dignity/USA Pamphlet.

1998: Homosexuality in Catholic Teaching and Practice, IN Culturefront. Vol. 7 No. 3 (Fall): 65-68.

PRIMIANO, Leonard Norman

1993a: Intrinsically Catholic: Vernacular Religion and Philadelphia's "Dignity". Ph.D. diss., Departments of Folklore and Folklife and Religious Studies.

1993b: "I Would Rather Be Fixated On the Lord": Women’s Religion, Men's Power, and the 'Dignity' Problem, New York Folklore, XIX: 89-103.

1995: Vernacular Religion and the Search for Method in Religious Folklife. Western Folklore 54: STONE, Jeff $37-56$.

1998: "The Truth Shall Make You Free": Dignity and the Gay Catholic Movement IN Culturefront. Vol. 7 No. 3 (Fall): 69-72.

WESTERMAN, William

1996: Politics and Folklore. In Jan Harold BRUNVAND (ed.) American Folklore: An Encyclopedia. New York: Garland Press, pp. 570-574. 